Analisis Kemampuan Pemahaman.... (Pepi Permana, Kiki Aryaningrum, Adrianus Dedy)

\title{
ANALISIS KEMAMPUAN PEMAHAMAN IPS PADA PESERTA DIDIK KELAS V SD NEGERI 1 UJUNG TANJUNG
}

\author{
Oleh : Pepi Permana, Kiki Aryaningrum, Adrianus Dedy \\ Email : kikiaryaningrum@yahoo.co.id, dedyadrianus30@gmail.com
}

(Universitas PGRI Palembang)

\begin{abstract}
Abstrak
Masalah pada penelitian ini adalah bagaimanakah tingkat kemampuan pemahaman IPS materi kegiatan ekonomi dan peranan guru terhadap Peserta Didik Kelas V di SD Negeri 1 Ujung Tanjung. Objek dalam penelitian ini adalah guru mata pelajaran IPS, siswa dan kepala SD Negeri 1 Ujung Tanjung. Metode penelitian dalam penelitian ini adalah metode deskriptif kualitatif. Teknik pengumpulan data meliputi tes, wawancara, dan dokumentasi, sedangkan teknik analisis data reduksi data, penyajian data dan penarikan kesimpulan. Berdasarkan hasil penelitian didapatkan bahwa tingkat pemahaman pemahaman IPS sebesar 77,25\% termasuk dalam kategori baik. Peranan guru adalah guru menjelaskan materi kegiatan ekonomi telah sesuai dengan kurikulum k-2013. Selain itu, guru telah menggunakan buku guru dan buku siswa. Buku guru berupa buku paket dan buku siswa berupa LKS. Tetapi, tidak menggunakan media. Hal ini disebabkan karena di dalam buku tersebut terdapat hal-hal yang menarik, seperti gambar. Metode yang diterapkan guru bervariatif yaitu metode ceramah, tanya jawab, dan demonstrasi.
\end{abstract}

Kata Kunci : Kemampuan Pemahaman IPS, Peserta Didik

\section{ANALYSIS OF IPS UNDERSTANDING ABILITIES IN STUDENTS CLASS V SD NEGERI 1 UJUNG TANJUNG}

\begin{abstract}
The problem in this research is what is the level of understanding of social studies material on economic activities and the role of teachers in Class $V$ students at SD Negeri 1 Ujung Tanjung. The objects in this study were the social studies subject teachers, students and principals of SD Negeri 1 Ujung Tanjung. The research method in this research is a qualitative descriptive method. Data collection techniques include tests, interviews, and documentation, while data analysis techniques are data reduction, data presentation and conclusion drawing. Based on the research results, it was found that the level of understanding of social studies understanding was $77.25 \%$, which was in the good category. The role of the teacher is the teacher to explain the material for economic activities in accordance with the $K-2013$ curriculum. In addition, teachers have used teacher books and student books. The teacher's books are in the form of textbooks and student books in the form of worksheets. However, not using the media. This is because the book contains interesting things, such as
\end{abstract}


Wahana Didaktika Vol. 18 No.3 September 2020 : 357-365

pictures. The methods applied by the teacher varied, namely the methods of lecturing, question and answer, and demonstrations.

Keywords: IPS Understanding Ability, Students

\section{A. PENDAHULUAN}

Pendidikan memiliki peran utama dalam pengembangan personal dan sosial, memengaruhi perubahan individu dan sosial, perdamaian, kebebasan, dan keadilan. Pendidikan harus memenuhi peran strategis dalam pengembangan manusia sebagai individu dan masyarakat untuk mengubah masyarakat dan memerlukan paradigma, tujuan baru, definisi baru tentang kualitas, inovasi pendekatan, program dan praktik (Kunandar, 2011:10).

Pendidikan sekolah dasar merupakan pendidikan yang awal bagi peserta didik. Pendidikan dasar merupakan pondasi yang melandasi pendidikan untuk jenjang-jenjang berikutnya. Pendidikan dasar berbentuk Sekolah Dasar (SD) dan Madrasah Ibtidaiyah (MI) atau bentuk lain yang sederajat. Pada pendidikan di sekolah dasar, peserta didik diharuskan menguasai berbagai mata pelajaran pokok yakni Agama dan Budi Pekerti, PKn, Bahasa Indonesia, Matematika, Ilmu Pengetahuan Alam (IPA), Ilmu Pengetahuan Sosial (IPS), Seni Budaya dan Prakarya, dan Pendidikan Jasmani, Olahraga dan Kesehatan.

Melalui mata pelajaran IPS, peserta didik diarahkan untuk dapat menjadi warga negara Indonesia yang demokratis, dan bertanggung jawab, serta warga dunia yang cinta damai”. Hal ini berarti pembelajaran Ilmu Pengetahuan Sosial (IPS) diterapkan di tingkat dasar seperti SD/MI/SDLB hingga ketingkat menengah seperti SMP/MTs/SMPLB dan memuat Geografi, Sejarah, Sosiologi, dan Ekonomi.

Berdasarkan hasil wawancara peneliti lakukan dengan wali kelas V di SD Negeri 1 Ujung Tanjung bernama Iid Susiana, S.Pd menyatakan bahwa bahwa kemampuan pemahaman IPS dari 32 perserta didik, dimana ada 12 peserta didik sudah memahami, sedangkan 22 peserta didik belum bisa memahami materi tersebut. Dari data hasil belajar tersebut, terlihat indikator yaitu peserta didik 
belum mampu mengidentifikasi jenis-jenis kegiatan ekonomi, belum dapat menjelaskan berbagai bentuk kegiatan ekonomi beserta contohnya, serta belum mampu memahami penyajian berbagai bentuk data terkait kegiatan ekonomi (tabel, diagram garis, grafik batang, gambar).

Seperti penelitian yang relevan dilakukan oleh Yayah Churiyah (2011) dengan judul "Analisis Tingkat Pemahaman Siswa Sekolah Dasar terhadap Penggunaan Ejaan". Dari hasil analisis, dapat diambil beberapa kesimpulan sebagai berikut: (a) Hampir seluruhnya siswa kelas VI SD Negeri 3 Ciseureuh Purwakarta sudah memahami penggunaan ejaan, khususnya siswa telah mampu menempatkan dan menggunakan huruf besar dalam menulis; (b) Hampir seluruhnya siswa kelas VI SD Negeri 3 Ciseureuh Purwakarta sudah memahami penggunaan ejaan, khususnya siswa telah mampu menempatkan dan menggunakan tanda baca dalam menulis; (c) Hampir seluruh siswa kelas VI SD Negeri 3 Ciseureuh Purwakarta mengetahui adanya hambatan yang menjadi kendala untuk mengembangkan kemampuan penggunaan haruf besar dan tanda baca dalam menulis. Hambatan-hambatan yang dimaksud adalah berupa dimilikinya sifat malas dan kurangnya latihan penggunaan ejaan dalam pembelajaran menulis.

Penelitian yang dilakukan oleh Nurani (2015) dengan judul Analisis Kesulitan-Kesulitan Belajar IPS Siswa Kelas IV Dalam Implementasi Kurikulum 2013 di SD Piloting Se-Kabupaten Gianyar Tahun Pelajaran 2014/2015. Hasil penelitian ini adalah (1) kesulitan belajar IPS siswa kelas IV dalam implementasi Kurikulum 2013 SD Piloting se-kabupaten Gianyar meliputi kesulitan pemahaman konsep IPS sebesar 61,04\% dari 86 siswa yang mengalami kesulitan belajar IPS dan kesulitan dalam keterampilan intelektual sebesar 76,74\% dari 86 siswa yang mengalami kesulitan belajar IPS di sekolah piloting tersebut, (2) faktor-faktor yang menjadi penyebab kesulitan-kesulitan belajar IPS siswa kelas IV dalam implementasi kurikulum 2013 di SD Piloting Kurikulum 2013 se-Kabupaten Gianyar meliputi faktor internal, yaitu minat dengan persentase $51,05 \%$, motivasi dengan persentase $50,75 \%$ dan bakat 
dengan persentase $49,38 \%$. Sedangkan faktor eksternal yang memberi pengaruh terhadap kesulitan belajar IPS siswa adalah proses pembelajaran dengan persentase pengaruh $52,71 \%$ dan sarana/prasarana sekolah dengan persentase $61,77 \%$.

Berdasarkan uraian di atas, maka peneliti merasa tertarik untuk melakukan penelitian dengan Judul Analisi Kemampuan Pemahaman IPS Pada Peserta Didik Kelas V di SD Negeri 1 Ujung Tanjung dengan rumusan masalah adalah Bagaimanakah tingkat kemampuan pemahaman IPS materi kegiatan ekonomi pada Peserta Didik Kelas V di SD Negeri 1 Ujung Tanjung. Bagaimanakah peranan guru terhadap pemahaman IPS materi kegiatan ekonomi pada Peserta Didik Kelas V di SD Negeri 1 Ujung Tanjung.

\section{B. METODOLOGI PENELITIAN}

Metode penelitian yang digunakan dalam penelitian ini adalah metode deskriptif kualitatif. Menurut Sugiyono (2017:1) metode penelitian deskriptif kualitatif adalah metode penelitian yang digunakan untuk meneliti pada kondisi objek yang alamiah, dengan peneliti sebagai instrumen kunci. Metode penelitian kualitatif digunakan untuk mendapatkan data yang mendalam, suatu data yang mengandung makna. Metode deskriptif kualitatif ini digunakan untuk mengungkapkan tingkat Kemampuan Pemahaman IPS Pada Peserta Didik Kelas V di SD Negeri 1 Ujung Tanjung. Teknik pengumpulan data meliputi tes, wawancara, dan dokumentasi, sedangkan teknik analisis data reduksi data, penyajian data dan penarikan kesimpulan.

\section{HASIL PENELITIAN DAN PEMBAHASAN}

Berdasarkan hasil penelitian diperoleh bahwa nilai rata-rata tingkat pemahaman siswa terhadap pembelajaran IPS sebesar 77,25. Nilai rata-rata tersebut terdapat pada interval 76-85\% yang termasuk dalam kategori baik. Dengan demikian, dapat disimpulkan bahwa tingkat kemampuan pemahaman IPS materi kegiatan ekonomi pada Peserta Didik Kelas V di SD Negeri 1 Ujung 
Analisis Kemampuan Pemahaman.... (Pepi Permana, Kiki Aryaningrum, Adrianus Dedy)

Tanjung termasuk dalam kategori baik. Hal ini sesuai dengan pendapat Nurani (2015) yang menyatakan bahwa, konsep-konsep dan keterampilan intelektual dalam pembelajaran IPS yang dikemas dalam soal tersebut sesungguhnya telah diajarkan kepada siswa. Namun dalam menjawab soal yang diberikan, siswa cenderung melupakan konsep-konsep tersebut.

Berdasarkan hasil wawancara dapat diketahui bahwa materi kegiatan ekonomi termasuk dalam materi yang sulit untuk dipahami, sehingga siswa akan mengalami kesulitan dalam memahaminya. Selain itu, hasil wawancara juga menyatakan bahwa tidak semua siswa dapat memahami ataupun menjelaskan tentang materi kegiatan ekonomi. Ini juga terkait pada hasil wawancara nomor 1 yaitu materi kegiatan ekonomi sulit dipahami. Berdasarkan hasil wawancara menyatakan bahwa siswa yang dapat mengklasifikasi kegiatan ekonomi. Selain itu, ada juga siswa yang belum mampu memahami materi kegiatan ekonomi tersebut.

Hal ini sesuai dengan hasil penelitian Nurani (2015:11) di SD Piloting Kabupaten Gianyar yaitu: (1) kesulitan belajar IPS siswa kelas IV dalam implementasi Kurikulum 2013 di SD Piloting se-kabupaten Gianyar meliputi kesulitan pemahaman konsep IPS sebesar 61,04\% dari 86 siswa yang mengalami kesulitan belajar IPS dan kesulitan dalam keterampilan intelektual sebesar 76,74\% dari 86 siswa yang mengalami kesulitan belajar IPS di sekolah piloting tersebut, (2) faktor-faktor yang menjadi penyebab kesulitankesulitan belajar IPS siswa kelas IV dalam implementasi kurikulum 2013 di SD Piloting Kurikulum 2013 se-Kabupaten Gianyar meliputi faktor internal yaitu minat dengan persentase $51,05 \%$, motivasi dengan persentase $50,75 \%$ dan bakat dengan persentase $49,38 \%$. Sedangkan faktor eksternal yang memberi pengaruh.

Berdasarkan hasil wawancara di atas, dapat diketahui bahwa guru telah menggunakan buku guru dan buku siswa. Buku guru berupa buku paket dan buku siswa juga berupa LKS. Berdasarkan hasil wawancara di atas, dapat diketahui bahwa guru kelas V di SD Negeri 1 Ujung Tanjung menerapkan 
berbagai metode. Metode yang diterapkan adalah metode ceramah,tanyajawab, dan demonstrasi. Berdasarkan hasil wawancara, dapat diketahui bahwa guru kelas V di SD Negeri 1 Ujung Tanjung hanya menggunakan buku guru dan buku siswa, tetapi tidak menggunakan media.

Dari hasil wawancara, guru menjelaskan bahwa proses pembelajaran yang telah dilakukan oleh guru terhadap materi kegiatan ekonomi telah baik. Hal ini disebabkan karena didalam buku tersebut terdapat hal-hal yang menarik, seperti gambar. Selainitu, materi kegiatan ekonomi telah sesuai dengan kurikulum k-2013. Hal ini sesuai dengan pendapat Lubis (2019:5) yang menyatakan bahwa Ilmu Pengetahuan Sosial (IPS) merupakan bidang studi yang mempelajari, menelaah, serta menganalisis gejala dan masalah sosial di masyarakat ditinjau dari berbagai aspek kehidupan secara terpadu. Perubahan dalam struktur pembelajaran IPS pada kurikulum 2013 juga menjadi tantangan tersendiri bagi guru mata pelajaran IPS.

Hasil wawancara dengan kepala sekolah menyatakan bahwa upaya untuk meningkatkan mutu pendidikan di SD Negeri 1 Ujung Tanjung dengan cara mengajak guru-guru untuk disiplin sehingga dapat memberikan/ mengajarkan contoh yang baik kepada peserta didik untuk berdisiplin, jujur dan sopan. Selain itu, proses pembelajaran yang telah dilakukan di SD Negeri 1 Ujung Tanjung pada tahun ini telah Baik. Hal ini karena penyampaian guru dengan peserta didik sudah terlaksanakan sesuai buku tema dan RPP yang sesuai dengan kurikulum. Hambatan bagi guru SD Negeri 1 Ujung Tanjung dalam menerapkan proses pembelajaran di sekolah adalah kurangnya media pembelajaran yang digunakan guru untuk proses belajar mengajar. Kemampuan guru dalam memanfaatkan sarana dan prasarana sekolah untuk menunjang materi kegaiatan ekonomi, sudah cukup baik. Program pembelajaran yang menunjang materi kegiatan ekonomi di SD Negeri 1 Ujung Tanjung belum ada, tetapi ekstrakurikuler telah ada.

Berdasarkan hasil wawancara ditemukan bahwa siswa merasa senang dalam mengikuti kegiatan pembelajaran IPS, khususnya materi kegiatan 
ekonomi. Hal ini disebabkan karena pembelajaran IPS banyak gambar-gambar. Selain itu, siswa juga menyatakan bahwa siswa pahami hanya membedakan jenis-jenis kegiatan ekonomi, yaitu pertanian, peternakan, dan perikanan. Hal ini sesuai dengan pendapat Syamsiyah (2018:57) yang menyatakan bahwa pembelajaran IPS pada siswa kelas V memberikan pengetahuan mengenai jenisjenis usaha perekonomian yang ada di masyarakat Indonesia beraneka ragam, di antaranya adalah pertanian, perdagangan, perikanan, peternakan, industri kerajinan, dan jasa.

Selain itu, siswa juga hanya memahami materi kegiatan ekonomi adalah tentang berjualan/bedagang. Hasil wawancara juga menyatakan bahwa siswa mampu membedakan jenis usaha, tetapi belum mampu memahami tentang pemberian contoh kegiatan ekonomi secara lebih detail. Siswa juga menyatakan bahwa cara gurumu dalam menjelaskan materi pembelajaran kegiatan ekonomi dengan menggunakan buku guru dan buku siswa, sedangkan media pembelajaran materi kegiatan ekonomi, belum digunakan. Kesulitan siswa dalam memahami materi kegiatan ekonomi terdapat pada memahami ketika belajar tentang tabeltabel dan juga ada kesulitan mengenai apa yang guru sampaikan.

Berdasarkan hasil wawancara yang telah dibuat, maka peranan guru terhadap pemahaman IPS materi kegiatan ekonomi pada Peserta Didik Kelas V di SD Negeri 1 Ujung Tanjung adalah sebagai berikut:

1. Guru menjelaskan materi kegiatan ekonomi telah sesuai dengan kurikulum $\mathrm{k}-2013$.

2. Guru telah menggunakan buku guru dan buku siswa. Buku guru berupa buku paket dan buku siswa juga berupa LKS. Tetapi, tidak menggunakan media. Hal ini disebabkan karena didalam buku tersebut terdapat hal-hal yang menarik, seperti gambar.

3. Metode yang diterapkan guru bervariatif yaitu metode ceramah, tanya jawab, dan demonstrasi.

4. Upaya untuk meningkatkan mutu pendidikan di SD Negeri 1 Ujung Tanjung dengan cara mengajak guru-guru untuk disiplin sehingga dapat 
memberikan/mengajarkan contoh yang baik kepada peserta didik unutk berdisiplin, jujur, dan sopan.

\section{SIMPULAN}

Berdasarkan hasil penelitian dapat disimpulkan sebagai berikut.

1. Berdasarkan hasil penelitian didapatkan bahwa tingkat pemahaman pemahaman IPS sebesar 77,25\% yang termasuk dalam kategoribaik.

2. Peranan guru terhadap pemahaman IPS materi kegiatan ekonomi pada Peserta Didik Kelas V di SD Negeri 1 Ujung Tanjung adalah sebagai berikut.

a. Guru menjelaskan materi kegiatan ekonomi telah sesuai dengan kurikulum k-2013.

b. Guru telah menggunakan buku guru dan buku siswa. Buku guru berupa buku paket dan buku siswa juga berupa LKS. Tetapi, tidak menggunakan media. Hal ini disebabkan karena didalam buku tersebut terdapat hal-hal yang menarik, seperti gambar.

c. Metode yang diterapkan guru bervariatif yaitu metode ceramah, tanya jawab, dan demonstrasi.

d. Upaya untuk meningkatkan mutu pendidikan di SD Negeri 1 Ujung Tanjung dengan cara mengajak guru-guru untuk disiplin sehingga dapat memberikan/mengajarkan contoh yang baik kepada peserta didik untuk disiplin, jujur dan sopan. 
Analisis Kemampuan Pemahaman.... (Pepi Permana, Kiki Aryaningrum, Adrianus Dedy)

\section{DAFTAR PUSTAKA}

Nurani, Gita Candra. (2015). Analisis Kesulitan-Kesulitan Belajar IPS Siswa Kelas IV Dalam Implementasi Kurikulum 2013 di SD Piloting SeKabupaten Gianyar Tahun Pelajaran 2014/2015. e-Journal PGSD Universitas Pendidikan Ganesha Volume 3 No 1 Tahun 2015.

Kunandar. (2011). Guru Professional. Jakarta: Raja Grafindo Persada

Lubis, Nur Apidah. (2019). Pendidikan IPS dalam Kurikulum 2013. Sidimpuan: Pendidikan Guru Madrasah Ibtidaiyah, Institut Agama Islam Negeri Padang.

Sugiyono. (2017). Metode Penelitian Kualitatif. Bandung: AlphaBheta.

Syamsiyah, Siti. (2018). Ilmu Pengetahuan Sosial untuk SD/MI kelas 5. Jakarta: Departeman Pendidikan Nasional.

Yayah, Churiyah. 2011. Analisis Tingkat Pemahaman Siswa Sekolah Dasar terhadap Penggunaan Ejaan. Jurnal Universitas Pendidikan Indonesia, Nomor 11April. 